\title{
Effects of in-yolk-sac administration of carvacrol on cholesterol resorption from yolk residuals and physiological adaptive indicators in broiler chicks exposed to neonatal fasting
}

\author{
Mir Hasan Beiranvand ${ }^{1}$, Heshmatollah Khosravinia ${ }^{1}$, Arash Azarfar ${ }^{1}$, and Ezatollah Rafiei Alavai ${ }^{2}$ \\ ${ }^{1}$ Department of Animal Science, Faculty of Agriculture, Lorestan University, Khorramabad, Lorestan, Iran \\ ${ }^{2}$ Department of Pathology, Faculty of Medicine, Lorestan University of Medical Sciences, Khorramabad, Iran
}

Correspondence to: H. Khosravinia (khosravi_fafa@yahoo.com)

Received: 26 November 2015 - Revised: 15 April 2016 - Accepted: 25 April 2016 - Published: 7 June 2016

\begin{abstract}
Three hundred and twenty Ross 308 male broiler chicks were used to examine effects of in-yolk-sac (IYS) administration of carvacrol on cholesterol resorption from yolk and physiological adaptive responses of broiler chicks subjected to post-hatch fasting periods of up to $72 \mathrm{~h}$. Effects of the four experimental treatments, namely non-handled control (NHCON), sham injection control (SICON), polysorbate-80 injection (POLS), and carvacrol injection (CARV), were examined in 5 replicates of 10 birds each. Liver proportional weight was greater in carvacrol-injected chicks compared with other birds $24 \mathrm{~h}$ post-hatch $(P<0.05)$. The mean blood glucose concentration was $199.0 \mathrm{mg} \mathrm{dL}^{-1}$ when chicks were removed from the hatcher baskets, and decreased in all birds after being subjected to a $72 \mathrm{~h}$ post-hatch fasting. However, the slope of decrease in serum concentration of glucose was slower in carvacrol-injected birds than in the other birds, and they had a greater plasma glucose level compared with NHCON and SICON birds after $72 \mathrm{~h}$ post-hatch fasting. Lower plasma cholesterol levels were observed in carvacrol-treated chicks compared with those subjected to the other treatments at $72 \mathrm{~h}$ post-hatch $(P<0.05)$. Blood concentration of calcium $(\mathrm{Ca})$ was greater in carvacrol-injected birds at $24 \mathrm{~h}$ post-hatch than in NHCON and SICON birds $(P<0.05)$, but at $72 \mathrm{~h}$ it significantly increased in all birds, with the exception of carvacrol-treated chicks, which had significantly lower blood Ca concentration $\left(11.17 \mathrm{mg} \mathrm{dL}^{-1}\right)$ compared with other birds $(P<0.05)$. Blood potassium concentration increased in polysorbate- 80 and carvacrol-injected chicks $24 \mathrm{~h}$ post-hatch compared with the NHCON and SICON birds $(P<0.05)$. In conclusion, the results of the current study revealed that there was no direct interaction between cholesterol and carvacrol leading to reduced cholesterol absorption from yolk sac in newly hatched broiler chicks.
\end{abstract}

\section{Introduction}

During the last two decades, phytogenic feed additives in animal nutrition have increasingly attracted attention regarding their potential role as alternatives to growth promoter antibiotics. Increasing demands for phyto-additives in poultry nutrition warrant further characterization of the effects of plantderived active components on poultry metabolism. Hypolipidemic and hypocholesterolemic effects of medicinal plants derivations, particularly Labiatea family plants, have been previously reported (Jiang et al., 2003; Kaimal et al., 2010;
El-Rokhel et al., 2010; Vijayaraj et al., 2011; Garcia, 2014; Saravanan and Ignacimuthu, 2015). However, the mode of action has not been fully investigated.

Direct interference of certain phytogenic active components on absorption of lipid constituents and cholesterol (Ostlund et al., 2003), reducing activity of liver enzymes involved in de novo fatty acids and cholesterol biosynthesis (Qureshi et al., 1983; Elson and Qureshi, 1995; Crowell, 1999), and inducing an increased ratio of anabolic to catabolic steroids(Khosravinia, 2015b) are the three suggested mechanisms for hypolipidemic and hypocholes- 
terolemic effects of certain active components of plants extracts and essential oils. Carvacrol is known as the principle active constituent of many Labiatea family plants, including rosemary and savory species. It comprises 92-94\% of Satureja khuzestanica essential oils (Hadian et al., 2011). Carvacrol and carvacrol-bearing essential oils are reported to have hypolipidemic and hypocholesterolemic effects in monogastric species, including rats, mice, and chickens (Abdollahi et al., 2003; Khosravinia, 2015b).

To characterize effects of carvacrol on lipid metabolism in details, initially its effects on lipid digestion and absorption need to be investigated. We think that newly hatched broiler chicks can be used as an animal model to investigate lipid absorption as they are mainly dependent on yolk sac lipids for their energy supply in the first hours after hatching. However, we were not able to find a report on using neonate chicks for the same purpose. While a chick is exposed to an environmental stressor during the early stage of life, prompt resorption of yolk sac lipids as energy sources and cholesterol as precursor for steroid biosynthesis in adrenal glands are vital (Puvadolpirod and Thaxton, 2000a). Therefore, any factor impeding lipids and cholesterol release and resorption from yolk sac may deteriorate their subsequent responses to stress. This study was aimed to examine effects of inter-yolk-sac administration of carvacrol on cholesterol resorption from yolk residuals and physiological adaptive responses demonstrated in newly hatched broiler chickens subjected to feed deprival up to $72 \mathrm{~h}$ post-hatch.

\section{Materials and methods}

\subsection{Experimental flock}

Four hundred Ross 308 male broiler chicks were purchased from a commercial hatchery. The chicks were hatched from eggs with an average weight of $68.7 \mathrm{~g}$ which were produced by a 65 -week breeder flock. Chicks were removed from the hatchers at 07:00 a.m. and immediately were allocated into boxes of 20 chicks each. Each box contained 10 experimental birds and 10 extra birds. The experimental chicks from each of the five boxes were wing-banded and subjected to the experimental treatments at the hatchery, namely non-handled control (NHCON), sham injection control (SICON), polysorbate-80 injection (POLS), and carvacrol injection (CARV). For CARV treatment, carvacrol (94\% purity) was provided from Khorraman laboratory, Lorestan, Iran, and mixed with polysorbate-80 $(1: 1 v / v)$ at a dose of $400 \mathrm{mg} \mathrm{mL}^{-1}$. A total of $0.6 \mathrm{~mL}$ of the solution was then injected into the yolk sac of the chicks. For POLS treatment, a dose of $400 \mathrm{mg} \mathrm{mL}^{-1}$ of polysorbate- 80 , an emulsifier agent, was injected into the yolk sac of the chicks. For SICON treatment, the chicks were caught and the needle was inserted at the same point, but nothing was injected. The NHCON birds received no injection and did not have a sham injection. All chicks left the hatchery at 08:00 and arrived at the farm at 09:30. According to our pre-hatch observation, during examination of the hatcher, the chicks spent on average $12 \mathrm{~h}$ in hatcher baskets before being checked out from the hatcher. Upon arrival at the farm, the chicks (of $15.2 \mathrm{~h}$ age) from each box were placed and brooded in one of the 20 floor pens in a grow-out broiler house. Pine shavings were used as the bedding material in each pen. Continuous lighting was provided by a single incandescent bulb in each pen. Besides experimental chicks, each pen contained 10 extra male chicks which received no other treatment. These extra chicks were kept to minimize the social effects caused by removal of experimental chicks. All the chicks were deprived of feed during the experimental period (up to $72 \mathrm{~h}$ post-hatch) but had free access to clean water.

\subsection{Live weight shrinkage and organ weight}

At 07:00, after removing the chicks from the hatcher and distributing them into boxes (corresponding to $0 \mathrm{~h}$ in this experiment), two chicks from each box were weighed and killed by slicing the chick's carotids arteries and/or its jugular vein for blood collection. The killed birds were manually processed by removing the skin and gently opening the abdominal cavity to collect and weigh the yolk sac and liver. The whole breast (skin removed) and left leg (thigh and drumstick skin removed) were dissected from each chick and weighed. The same procedure was repeated using 10 chicks at 24,48 , and $72 \mathrm{~h}$ post-hatch feed deprival.

\subsection{Physiological measurements}

Blood samples were collected from the chicks killed at 0 , 24,48 , and $72 \mathrm{~h}$ post-hatch and kept at $35^{\circ} \mathrm{C}$ for $1 \mathrm{~h}$ to coagulate, and were thereafter, along with all of the killed hatchlings, kept at $4{ }^{\circ} \mathrm{C}$. Blood samples were centrifuged at $2300 \times g$ for $10 \mathrm{~min}$ to harvest serum. Harvested serum was stored at $-20{ }^{\circ} \mathrm{C}$ pending further analyses. Serum concentrations of glucose (GLU), albumins (ALB), total proteins (TP), triglycerides (TG), cholesterol (CHO), high-density lipoproteins (HDL), low-density lipoproteins (LDL), calcium (Ca), phosphorous $(\mathrm{P})$, sodium $(\mathrm{Na})$, and potassium $(\mathrm{K})$ were determined using an autoanalyzer (Selectra E autoanalyzer, Sr. No. 8-7140, Vital Scientific, Netherlands). The analyzer employed enzymatic procedures using SEPPIM diagnostic kits (SEPPIM S.A.S., Zone Industrielle, 61500, SEES, France) in two replicates, at $25^{\circ} \mathrm{C}$, based on the methods described by Elliott (1984). Yolk concentration of total cholesterol and total lipids were measured using the same diagnostic kits in all sampling times.

\subsection{Statistical analysis}

Data were analyzed using a completely randomized blocks design with four treatments and five replicates. All data were analyzed using PROC MIXED of SAS 9.2 (SAS Institute, 
Table 1. Total cholesterol and total lipids concentration in yolk sac in the chicks subjected to experimental treatments, namely non-handled control (NHCON), sham injection control (SICON), polysorbate-80 injection (POLS), and carvacrol injection (CARV), in post-hatch sampling times.

\begin{tabular}{|c|c|c|c|c|c|c|}
\hline \multirow[t]{2}{*}{ Parameter and post-hatch sampling age } & \multicolumn{4}{|c|}{ Treatments } & \multirow[b]{2}{*}{ SEM } & \multirow[b]{2}{*}{$p$ value } \\
\hline & NHCON & SICON & POLS & CARV & & \\
\hline \multicolumn{7}{|l|}{ Cholesterol (mg $\left.2 \mathrm{~g}^{-1}\right)$} \\
\hline $0 \mathrm{~h}$ & 128.27 & 128.27 & 128.27 & 126.27 & 8.285 & 0.7423 \\
\hline $24 \mathrm{~h}$ & $112.33^{\mathrm{a}}$ & $124.25^{\mathrm{a}}$ & $97.40^{\mathrm{b}}$ & $112.95^{\mathrm{a}}$ & 7.841 & 0.0453 \\
\hline $48 \mathrm{~h}$ & 102.42 & 106.63 & 102.02 & 128.74 & 6.089 & 0.0841 \\
\hline $72 \mathrm{~h}$ & 176.13 & 213.75 & 192.91 & 144.14 & 10.655 & 0.1280 \\
\hline$b^{1}$ & $0.556^{\mathrm{ns}}$ & $0.995^{\mathrm{ns}}$ & $0.827^{\mathrm{ns}}$ & $0.289^{\mathrm{ns}}$ & & \\
\hline$R^{2}$ linear model & 0.279 & 0.413 & 0.339 & 0.490 & & \\
\hline \multicolumn{7}{|l|}{ Total lipids (g $100 \mathrm{~g}^{-1}$ ) } \\
\hline $0 \mathrm{~h}$ & 35.51 & 36.55 & 36.55 & 36.55 & 1.007 & 0.8501 \\
\hline $24 \mathrm{~h}$ & $31.05^{\mathrm{a}}$ & $33.49^{\mathrm{a}}$ & $28.71^{b}$ & $33.81^{\mathrm{a}}$ & 2.315 & 0.0111 \\
\hline $48 \mathrm{~h}$ & 24.32 & 22.03 & 25.83 & 26.51 & 2.195 & 0.2913 \\
\hline $72 \mathrm{~h}$ & 16.55 & 20.12 & 24.18 & 18.57 & 1.260 & 0.1023 \\
\hline$b^{1}$ & $-0.260^{* *}$ & $-0.253^{*}$ & $-0.170^{*}$ & $-0.255^{* *}$ & & \\
\hline$R^{2}$ linear model & 0.992 & 0.918 & 0.925 & 0.961 & & \\
\hline
\end{tabular}

a-b Means within a row with no common superscript differ significantly $(P<0.05) .{ }^{1}$ Regression coefficient of post-hatch sampling age vs. parameter. Probability of $\beta \neq 0$ is indicated, where ns stands for non-significant. * Significantly different at $P \leq 0.05$; ${ }^{* *}$ significantly different at $P \leq 0.01$.

2002) considering blocks as a random effect. For all statistical analyses, significance was declared at $P \leq 0.05$, unless otherwise stated. Fisher's protected least significant difference (LSD) test was used for multiple treatment comparisons using the LSMEANS of SAS 9.2 (SAS, 2002), with letter grouping obtained using the SAS pdmix 800 macro (Saxton, 2000). Regression analyses were performed within each treatment to determine the relationships between post-hatch fasting times and each of the variables assessed (Steel and Torrie, 1980).

\section{Results}

Liver proportional weight was greater in CARV chicks compared with the other birds at $24 \mathrm{~h}$ post-hatch $(P<0.05)$. Significant negative linear regression coefficients were found between post-hatch sampling time and yolk concentration of total lipid concentration in control and CARV-treated birds, suggesting a linear trend of decreasing yolk lipids over the first $72 \mathrm{~h}$ of a chick's life regardless of treatment received (Table 1). Mean serum concentration of GLU was $199.00 \mathrm{mg} \mathrm{dL}^{-1}$ when chicks were removed from the hatcher baskets and decreased in all birds by extending the post-hatch fasting period up to $72 \mathrm{~h}$. However, the rate of GLU decrease in carvacrol-injected birds was lower, and they had a greater serum GLU level compared with NHCON and SICON birds at $72 \mathrm{~h}$ post-hatch. No difference was observed in serum CHOL concentration between the birds at hatch, 24, 48, and 72-h post-hatch, but lower serum CHOL level was observed in CARV chicks compared with the other birds at $72 \mathrm{~h}$ posthatch $(P<0.05)$. The same trend was also observed in serum LDL concentration where carvacrol-treated chicks had lower serum LDL compared with NHCON-, SICON-, and POLStreated birds at $72 \mathrm{~h}$ post-hatch $(P<0.05)$. Significant negative linear regression coefficients were found between posthatch sampling time, body weight, and yolk sac percentage in all groups. Significant positive linear relationships were observed between post-hatch sampling time and serum TP and ALB concentrations in CARV-treated birds, demonstrating a linear trend in elevation of both parameters during the first $72 \mathrm{~h}$ of a chick's life. Unlike CARV-injected chicks, significant and positive linear regression coefficients were found between post-hatch sampling time and serum CHOL concentration in all control birds, suggesting that CHOL may have been absorbed from circulation in CARV-treated birds in response to the carvacrol-imposed stress as indicated by increased liver weight and serum TP and ALB concentrations. Serum Ca concentration was greater in CARVinjected birds at $24 \mathrm{~h}$ post-hatch compared with NHCON and SICON chicks, but at $72 \mathrm{~h}$ post-hatch fasting it significantly increased in all birds, with the exception of carvacroltreated chicks, which had a significantly lower Ca concentration $\left(11.17 \mathrm{mg} \mathrm{dL}^{-1}\right)$ compared with other birds $(P<0.05)$. Blood Na concentration was elevated in the chicks that received polysorbate injection at $24 \mathrm{~h}$ post-hatch, but the differences were only significant when they were compared 
Table 2. Body weight, yolk sac weight, and liver, breast, and leg percentage (total body weight) in chicks subjected to experimental treatments, namely non-handled control (NHCON), sham injection control (SICON), polysorbate-80 injection (POLS), and carvacrol injection (CARV), in post-hatch sampling times.

\begin{tabular}{|c|c|c|c|c|c|c|}
\hline \multirow[t]{2}{*}{ Parameter and post-hatch sampling age } & \multicolumn{4}{|c|}{ Treatments } & \multirow[b]{2}{*}{ SEM } & \multirow[b]{2}{*}{$p$ value } \\
\hline & NHCON & SICON & POLS & CARV & & \\
\hline \multicolumn{7}{|l|}{ Body weight (g) } \\
\hline $\mathrm{Oh}$ & 47.03 & 46.92 & 46.78 & 46.79 & 0.2338 & 0.8168 \\
\hline $24 \mathrm{~h}$ & 45.77 & 46.54 & 46.62 & 45.33 & 0.9325 & 0.7206 \\
\hline $48 \mathrm{~h}$ & 44.08 & 43.88 & 45.40 & 43.75 & 0.8721 & 0.5445 \\
\hline $72 \mathrm{~h}$ & 40.79 & 42.10 & 41.41 & 39.59 & 0.6657 & 0.1068 \\
\hline$b^{1}$ & $-0.093^{*}$ & $-0.085^{*}$ & $-0.103^{*}$ & $-0.098^{*}$ & & \\
\hline$R^{2}$ linear model & 0.865 & 0.982 & 0.840 & 0.930 & & \\
\hline \multicolumn{7}{|l|}{ Yolk sac weight (g) } \\
\hline $\mathrm{Oh}$ & 6.83 & 6.55 & 6.97 & 7.09 & 0.5210 & 0.9832 \\
\hline $24 \mathrm{~h}$ & 5.20 & 5.73 & 5.63 & 5.04 & 0.3361 & 0.4066 \\
\hline $48 \mathrm{~h}$ & 3.73 & 3.93 & 3.20 & 2.87 & 0.1674 & 0.2969 \\
\hline $72 \mathrm{~h}$ & 2.13 & 1.59 & 1.92 & 1.49 & 0.0969 & 0.3486 \\
\hline$b^{1}$ & $-0.065^{* *}$ & $-0.071^{*}$ & $-0.074^{*}$ & $-0.080^{*}$ & & \\
\hline$R^{2}$ linear model & 0.999 & 0.963 & 0.985 & 0.990 & & \\
\hline \multicolumn{7}{|l|}{ Liver percentage } \\
\hline $0 \mathrm{~h}$ & 1.25 & 1.25 & 1.21 & 1.19 & 0.0167 & 0.9043 \\
\hline $24 \mathrm{~h}$ & $1.30^{\mathrm{b}}$ & $1.32^{\mathrm{b}}$ & $1.32^{\mathrm{b}}$ & $1.73^{\mathrm{a}}$ & 0.1083 & 0.0157 \\
\hline $48 \mathrm{~h}$ & 1.35 & 1.36 & 1.45 & 1.44 & 0.0112 & 0.2553 \\
\hline $72 \mathrm{~h}$ & 1.45 & 1.53 & 1.42 & 1.36 & 0.0137 & 0.1423 \\
\hline$b^{1}$ & $0.003^{*}$ & $0.004^{*}$ & $0.003^{\mathrm{ns}}$ & $0.001^{\mathrm{ns}}$ & & \\
\hline$R^{2}$ linear model & 0.968 & 0.913 & 0.716 & 0.013 & & \\
\hline \multicolumn{7}{|l|}{ Breast percentage } \\
\hline $0 \mathrm{~h}$ & 1.51 & 1.62 & 1.31 & 1.57 & 0.0451 & 0.5621 \\
\hline $24 \mathrm{~h}$ & 1.44 & 1.31 & 1.36 & 1.39 & 0.0944 & 0.8221 \\
\hline $48 \mathrm{~h}$ & 1.40 & 1.44 & 1.36 & 1.36 & 0.0178 & 0.7888 \\
\hline $72 \mathrm{~h}$ & 1.29 & 1.33 & 1.25 & 1.22 & 0.0177 & 0.6123 \\
\hline$b^{1}$ & $0.003^{*}$ & $0.003^{\mathrm{ns}}$ & $0.008^{\mathrm{ns}}$ & $0.005^{*}$ & & \\
\hline$R^{2}$ linear model & 0.966 & 0.444 & 0.204 & 0.936 & & \\
\hline \multicolumn{7}{|l|}{ Leg percentage } \\
\hline $\mathrm{Oh}$ & 3.25 & 3.06 & 3.04 & 2.72 & 0.0424 & 0.1925 \\
\hline $24 \mathrm{~h}$ & 2.83 & 2.98 & 3.15 & 2.52 & 0.1643 & 0.0543 \\
\hline $48 \mathrm{~h}$ & 2.99 & 2.99 & 3.09 & 3.03 & 0.0211 & 0.7243 \\
\hline $72 \mathrm{~h}$ & 2.81 & 3.07 & 2.89 & 2.83 & 0.0216 & 0.0812 \\
\hline$b^{1}$ & $-0.005^{\mathrm{ns}}$ & $0.000^{\mathrm{ns}}$ & $-0.002^{\mathrm{ns}}$ & $0.004^{\mathrm{ns}}$ & & \\
\hline$R^{2}$ linear model & 0.534 & 0.014 & 0.340 & 0.263 & & \\
\hline
\end{tabular}

a-b Means within a row with no common superscript differ significantly $(P<0.05) .{ }^{1}$ Regression coefficient of post-hatch sampling age vs. parameter. Probability of $\beta \neq 0$ is indicated, where ns stands non-significant. ${ }^{*}$ Significantly different at $P \leq 0.05$; $* *$ significantly different at $P \leq 0.01$. 
Table 3. Blood glucose, total protein, and albumin concentration in chicks subjected to experimental treatments, namely non-handled control (NHCON), sham injection control (SICON), polysorbate-80 injection (POLS) and carvacrol injection (CARV), in post-hatch sampling times.

\begin{tabular}{|c|c|c|c|c|c|c|}
\hline \multirow[t]{2}{*}{ Parameter and post-hatch sampling age } & \multicolumn{4}{|c|}{ Treatments } & \multirow[b]{2}{*}{ SEM } & \multirow[b]{2}{*}{$p$ value } \\
\hline & NHCON & SICON & POLS & CARV & & \\
\hline \multicolumn{7}{|l|}{ Glucose $\left(\mathrm{mg} \mathrm{dL}^{-1}\right)$} \\
\hline $0 \mathrm{~h}$ & 195.00 & 198.90 & 199.75 & 206.50 & 10.6915 & 0.7346 \\
\hline $24 \mathrm{~h}$ & 174.93 & 179.00 & 163.53 & 189.00 & 9.0960 & 0.1221 \\
\hline $48 \mathrm{~h}$ & $149.60^{\mathrm{b}}$ & $223.27^{\mathrm{a}}$ & $190.71^{\mathrm{ab}}$ & $165.47^{\mathrm{ab}}$ & 9.5148 & 0.0430 \\
\hline $72 \mathrm{~h}$ & $99.29^{b}$ & $97.67^{\mathrm{b}}$ & $132.27^{\mathrm{ab}}$ & $154.47^{\mathrm{a}}$ & 8.5725 & 0.0004 \\
\hline$b^{1}$ & $-1.321^{*}$ & $-1.099^{\mathrm{ns}}$ & $0.739^{\mathrm{ns}}$ & $0.757^{* *}$ & & \\
\hline$R^{2}$ linear model & 0.955 & 0.382 & 0.553 & 0.982 & & \\
\hline \multicolumn{7}{|l|}{ Total proteins $\left(\mathrm{mg} \mathrm{dL}^{-1}\right)$} \\
\hline $\mathrm{Oh}$ & 1.26 & 2.10 & 2.25 & 2.10 & 0.2456 & 0.4893 \\
\hline $24 \mathrm{~h}$ & 2.40 & 2.40 & 2.50 & 3.16 & 0.4473 & 0.5734 \\
\hline $48 \mathrm{~h}$ & 4.96 & 3.36 & 4.33 & 4.96 & 0.2885 & 0.1684 \\
\hline $72 \mathrm{~h}$ & 6.17 & 6.40 & 7.60 & 5.56 & 0.3681 & 0.2615 \\
\hline$b^{1}$ & $0.073^{*}$ & $0.059^{\mathrm{ns}}$ & $0.076^{\mathrm{ns}}$ & $0.051^{*}$ & & \\
\hline$R^{2}$ linear model & 0.976 & 0.835 & 0.881 & 0.968 & & \\
\hline \multicolumn{7}{|l|}{ Albumins (mg dL $\left.{ }^{-1}\right)$} \\
\hline $\mathrm{Oh}$ & 0.60 & 1.30 & 1.20 & 1.20 & 0.1003 & 0.1016 \\
\hline $24 \mathrm{~h}$ & 1.12 & 1.16 & 1.68 & 1.32 & 0.2894 & 0.5119 \\
\hline $48 \mathrm{~h}$ & 1.60 & 1.68 & 1.53 & 2.76 & 0.1965 & 0.2133 \\
\hline $72 \mathrm{~h}$ & 3.30 & 3.40 & 4.28 & 3.32 & 0.2295 & 0.3702 \\
\hline$b^{1}$ & $0.036^{\mathrm{ns}}$ & $0.029^{\mathrm{ns}}$ & $0.038^{\mathrm{ns}}$ & $0.033^{*}$ & & \\
\hline$R^{2}$ linear model & 0.899 & 0.733 & 0.687 & 0.917 & & \\
\hline
\end{tabular}

a-b Means within a row with no common superscript differ significantly $(P<0.05) .{ }^{1}$ Regression coefficient of post-hatch sampling age vs. parameter. Probability of $\beta \neq 0$ is indicated, where ns stands for non-significant. ${ }^{*}$ Significantly different at $P \leq 0.05$; ${ }^{* *}$ significantly different at $P \leq 0.01$.

with NHCON birds $(P<0.05)$. Serum K concentration was higher in polysorbate- and carvacrol-injected chicks compared with the NHCON and SICON birds $24 \mathrm{~h}$ post-hatch $(P<0.05)$.

\section{Discussion}

Yolk sac residual of a newly hatched broiler chick approximately contains $45 \mathrm{mgg}^{-1}$ of cholesterol (Connor et al., 1969). Cholesterol resorption from yolk sac plays a vital role in post-hatch normal growth and helps neonate chicks to deal with environmental distresses (Jamroz et al., 2004). Serum cholesterol of a newly hatched chick which seems to originate solely from yolk residuals drops from 400-500 to 120$140 \mathrm{mg}$ per $100 \mathrm{~mL}$ after 14 to 17 days, which is the reported range for older chicks. After hatching, a chick develops its own mechanisms for cholesterol synthesis and excretion (Connor et al., 1969). In chickens, cholesterol and cholesterol derivatives (steroid hormones and bile acids) are essential metabolites for the endocrine system, regulation of cell membrane processes, and adsorption of dietary lipids. Cholesterol and its fatty acyl esters are also important structural components of membranes. Cholesterol also serves as a precursor for the synthesis of steroid hormones, vitamin $\mathrm{D}$, and bile salts, which are important in fat absorption from the small intestine into the blood circulation system and secretion of liver waste products through feces (e.g., bilirubin). The body balance of cholesterol is controlled by the liver, which regulates the turnover rate of cholesterol levels via lipoprotein particles (Teekell et al., 1975).

The results of the current study reveal that carvacrol did not interfere with cholesterol absorption from yolk sac. A high concentration of cholesterol in yolk sac along with direct IYS injection of carvacrol provided an opportunity to monitor any interaction between absorption of yolk sac cholesterol and IYS-injected carvacrol. In this study, it was hypothesized that if there is an interaction between absorption of yolk sac cholesterol and IYS-injected carvacrol, or in other words if carvacrol has a tendency to bind with yolk sac cholesterol and inhibit or reduce its absorption from yolk contents, it should be reflected in serum concentration of cholesterol. Moreover, the response of chicks to post-hatch fasting stress should be lower due to a lack of adequate cholesterol in blood flux. In fasted chicks, due to the lack 
Table 4. Blood lipid constituent concentrations in chicks subjected to experimental treatments, namely non-handled control (NHCON), sham injection control (SICON), polysorbate-80 injection (POLS), and carvacrol injection (CARV), in post-hatch sampling times.

\begin{tabular}{|c|c|c|c|c|c|c|}
\hline \multirow[t]{2}{*}{ Parameter and post-hatch sampling age } & \multicolumn{4}{|c|}{ Treatments } & \multirow[b]{2}{*}{ SEM } & \multirow[b]{2}{*}{$p$ value } \\
\hline & NHCON & SICON & POLS & CARV & & \\
\hline \multicolumn{7}{|l|}{ Triglycerides $\left(\mathrm{mg} \mathrm{dL}^{-1}\right)$} \\
\hline $0 \mathrm{~h}$ & 139.50 & 186.00 & 178.50 & 185.00 & 11.5690 & 0.4736 \\
\hline $24 \mathrm{~h}$ & 144.93 & 171.53 & 166.80 & 180.00 & 14.8686 & 0.3945 \\
\hline $48 \mathrm{~h}$ & 208.40 & 196.40 & 235.29 & 196.80 & 16.2928 & 0.8221 \\
\hline $72 \mathrm{~h}$ & 215.00 & 184.40 & 233.20 & 184.80 & 9.0872 & 0.1646 \\
\hline$b^{1}$ & $1.225^{\mathrm{ns}}$ & $0.086^{\mathrm{ns}}$ & $0.985^{\mathrm{ns}}$ & $0.069^{\mathrm{ns}}$ & & \\
\hline$R^{2}$ linear model & 0.867 & 0.067 & 0.705 & 0.086 & & \\
\hline \multicolumn{7}{|l|}{ Cholesterol $\left(\mathrm{mg} \mathrm{dL}^{-1}\right)$} \\
\hline $\mathrm{Oh}$ & 438.00 & 459.00 & 462.00 & 473.50 & 27.2639 & 0.8378 \\
\hline $24 \mathrm{~h}$ & 567.60 & 576.00 & 588.80 & 590.80 & 34.2235 & 0.347 \\
\hline $48 \mathrm{~h}$ & 743.60 & 669.60 & 670.29 & 786.80 & 32.1812 & 0.5903 \\
\hline $72 \mathrm{~h}$ & $918.50^{\mathrm{a}}$ & $844.13^{\mathrm{a}}$ & $918.00^{\mathrm{a}}$ & $714.80^{\mathrm{b}}$ & 30.1557 & 0.0267 \\
\hline$b^{1}$ & $6.824^{* *}$ & $5.273^{* *}$ & $6.122^{*}$ & $3.870^{\mathrm{ns}}$ & & \\
\hline$R^{2}$ linear model & 0.997 & 0.984 & 0.949 & 0.734 & & \\
\hline \multicolumn{7}{|l|}{$\mathrm{HDL}\left(\mathrm{mg} \mathrm{dL}^{-1}\right)$} \\
\hline $0 \mathrm{~h}$ & 186.00 & 192.00 & 240.00 & 210.00 & 9.7318 & 0.2563 \\
\hline $24 \mathrm{~h}$ & 260.87 & 237.80 & 232.80 & 268.80 & 15.1698 & 0.2747 \\
\hline $48 \mathrm{~h}$ & 279.20 & 229.60 & 244.29 & 268.87 & 7.4566 & 0.0842 \\
\hline $72 \mathrm{~h}$ & 291.00 & 278.60 & 293.67 & 256.00 & 7.3103 & 0.2549 \\
\hline$b^{1}$ & $1.402^{\mathrm{ns}}$ & $1.060^{\mathrm{ns}}$ & $0.732^{\mathrm{ns}}$ & $0.575^{\mathrm{ns}}$ & & \\
\hline$R^{2}$ linear model & 0.824 & 0.833 & 0.653 & 0.397 & & \\
\hline \multicolumn{7}{|l|}{ LDL } \\
\hline $0 \mathrm{~h}$ & 220.50 & 287.50 & 184.50 & 245.00 & 26.1730 & 0.5318 \\
\hline $24 \mathrm{~h}$ & 243.80 & 306.15 & 296.33 & 284.40 & 26.8137 & 0.3803 \\
\hline $48 \mathrm{~h}$ & 420.73 & 398.40 & 384.86 & 467.80 & 26.3542 & 0.7004 \\
\hline $72 \mathrm{~h}$ & 577.64 & 536.33 & 575.20 & 419.87 & 23.7270 & 0.0577 \\
\hline$b^{1}$ & $5.282^{*}$ & $3.550^{*}$ & $5.323^{*}$ & $2.986^{\mathrm{ns}}$ & & \\
\hline$R^{2}$ linear model & 0.934 & 0.913 & 0.973 & 0.736 & & \\
\hline
\end{tabular}

of access to feed, birds are mainly dependent on yolk reservoir nutrients, including cholesterol, to fulfill their body requirements (Gonzales et al., 2003). In such birds, decreased availability of cholesterol is anticipated as the blood flux is promptly exhausted while metabolism demands continue, and further cholesterol is needed to combat stress because of increased corticoid synthesis. However, the results showed that cholesterol resorbed from yolk contents in CARV chicks at a constant rate during the $72 \mathrm{~h}$ post-hatch. In the NHCONand SICON-birds, cholesterol was also absorbed following the same trend as CARV-injected chicks.

No difference was observed in whole body weight loss or in breast and thighs between carvacrol-injected and control chicks during the post-hatch fasting period. If carvacrol interfered with cholesterol in yolk contents, a greater body weight loss would be expected in carvacrol-treated birds as an indication of tissue degradation in response to fulfilling metabolic demands for cholesterol required for corticoid biosynthesis. Such degradations were anticipated to occur in breast muscle at a greater rate than in thighs (Khosravinia, 2015a). Considering the current practices in production and transportation, newly hatched chicks are frequently subjected to fasting in the first $24 \mathrm{~h}$ after hatching. The adverse effects of fasting, among many other stressors, on muscle degradation for gluconeogenesis during the critical early hours of life need further investigation as birds may not be able to compensate for such losses until the final stages of their commercial life (Tankson et al., 2001; Puvadolpirod and Thaxton, 2000a, c). The associations between blood total protein concentration and blood albumin concentration with 
Table 5. Blood electrolyte concentrations in chicks subjected to experimental treatments, namely non-handled control (NHCON), sham injection control (SICON), polysorbate-80 injection (POLS), and carvacrol injection (CARV), in post-hatch sampling times.

\begin{tabular}{|c|c|c|c|c|c|c|}
\hline \multirow[t]{2}{*}{ Parameter and post-hatch sampling age } & \multicolumn{4}{|c|}{ Treatments } & \multirow[b]{2}{*}{ SEM } & \multirow[b]{2}{*}{$p$ value } \\
\hline & NHCON & SICON & POLS & CARV & & \\
\hline \multicolumn{7}{|l|}{$\mathrm{Ca}\left(\mathrm{mg} \mathrm{dL}^{-1}\right)$} \\
\hline $0 \mathrm{~h}$ & 7.53 & 10.80 & 9.48 & 8.25 & 0.8098 & 0.4713 \\
\hline $24 \mathrm{~h}$ & $8.82^{\mathrm{b}}$ & $9.20^{\mathrm{b}}$ & $8.32^{\mathrm{b}}$ & $10.44^{\mathrm{a}}$ & 0.4771 & 0.0116 \\
\hline $48 \mathrm{~h}$ & $9.80^{\mathrm{b}}$ & $9.20^{\mathrm{b}}$ & $10.20^{\mathrm{ab}}$ & $11.92^{\mathrm{a}}$ & 0.3626 & 0.0263 \\
\hline $72 \mathrm{~h}$ & $14.79^{\mathrm{a}}$ & $12.55^{\mathrm{ab}}$ & $13.35^{\mathrm{ab}}$ & $11.17^{\mathrm{b}}$ & 0.3996 & 0.0277 \\
\hline$b^{1}$ & $0.096^{\mathrm{ns}}$ & $0.022^{\mathrm{ns}}$ & $0.058^{\mathrm{ns}}$ & $0.439^{\mathrm{ns}}$ & & \\
\hline$R^{2}$ linear model & 0.860 & 0.187 & 0.664 & 0.689 & & \\
\hline \multicolumn{7}{|l|}{$\mathrm{P}\left(\mathrm{mg} \mathrm{dL}^{-1}\right)$} \\
\hline $0 \mathrm{~h}$ & 7.98 & 9.80 & 9.90 & 10.03 & 0.6495 & 0.6732 \\
\hline $24 \mathrm{~h}$ & 8.03 & 9.32 & 8.65 & 10.23 & 0.9435 & 0.3999 \\
\hline $48 \mathrm{~h}$ & 17.63 & 12.80 & 16.19 & 17.84 & 1.1586 & 0.3872 \\
\hline $72 \mathrm{~h}$ & 20.82 & 21.22 & 22.49 & 16.75 & 1.2444 & 0.3942 \\
\hline$b^{1}$ & $0.203^{\mathrm{ns}}$ & $0.160^{\mathrm{ns}}$ & $0.192^{\mathrm{ns}}$ & $0.117^{\mathrm{ns}}$ & & \\
\hline$R^{2}$ linear model & 0.888 & 0.790 & 0.849 & 0.744 & & \\
\hline \multicolumn{7}{|l|}{$\mathrm{Na}\left(\mathrm{mg} \mathrm{dL}{ }^{-1}\right)$} \\
\hline $0 \mathrm{~h}$ & 166.00 & 169.67 & 167.50 & 169.50 & 1.5477 & 0.8078 \\
\hline $24 \mathrm{~h}$ & $164.07^{\mathrm{b}}$ & $168.60^{\mathrm{ab}}$ & $173.93^{\mathrm{a}}$ & $168.00^{\mathrm{ab}}$ & 2.1656 & 0.0210 \\
\hline $48 \mathrm{~h}$ & 170.27 & 173.80 & 170.71 & 171.80 & 0.8821 & 0.4970 \\
\hline $72 \mathrm{~h}$ & 172.57 & 172.13 & 169.27 & 173.20 & 1.1539 & 0.6332 \\
\hline$b^{1}$ & $0.109^{\mathrm{ns}}$ & $0.053^{\mathrm{ns}}$ & $0.008^{\mathrm{ns}}$ & $0.063^{\mathrm{ns}}$ & & \\
\hline$R^{2}$ linear model & 0.749 & 0.479 & 0.488 & 0.695 & & \\
\hline \multicolumn{7}{|l|}{$\mathrm{K}\left(\mathrm{mg} \mathrm{dL}^{-1}\right)$} \\
\hline $0 \mathrm{~h}$ & 7.05 & 6.58 & 6.90 & 6.85 & 0.1049 & 0.4213 \\
\hline $24 \mathrm{~h}$ & $6.74^{\mathrm{b}}$ & $6.61^{\mathrm{b}}$ & $7.45^{\mathrm{a}}$ & $6.87^{\mathrm{ab}}$ & 0.2136 & 0.0374 \\
\hline $48 \mathrm{~h}$ & 7.04 & 7.20 & 7.10 & 7.23 & 0.1216 & 0.9380 \\
\hline $72 \mathrm{~h}$ & 7.21 & 7.80 & 7.13 & 7.08 & 0.1662 & 0.3903 \\
\hline$b^{1}$ & $0.003^{\mathrm{ns}}$ & $0.018^{*}$ & $0.001^{\mathrm{ns}}$ & $0.004^{\mathrm{ns}}$ & & \\
\hline$R^{2}$ linear model & 0.272 & 0.909 & 0.034 & 0.0559 & & \\
\hline
\end{tabular}

stress responses in broiler chickens are well documented $(\mathrm{Pu}-$ vadolpirod and Thaxton, 2000a). In the current study, a uniform response of increased blood total proteins and albumins was observed in all control as well as CARV-injected birds as a further indication of no interaction between IYS injection of carvacrol and absorption of yolk sac cholesterol during the post-hatch fasting period.

Stress at any stage of life (Puvadolpirod and Thaxton, 2000b; Mikec et al., 2006), especially during the neonatal period (Gonzales et al., 2003; Khosravinia, 2015c), causes notable changes in blood concentrations of lipid constituents (TG, HDL, and LDL) as well as in blood concentrations of electrolytes ( $\mathrm{Ca}, \mathrm{P}, \mathrm{Na}$, and $\mathrm{K})$ in broiler chickens. The trends of change observed in blood lipid constituents and blood electrolytes of chicks in response to the neonatal fasting period were in the line with the previous findings of Khosravinia (2015c). Furthermore, the lack of difference among NHCON-, SICON-, POLS-, and CARV-treated birds with regard to blood lipid constituents and electrolytes once again was an indication of no direct pre-absorption interaction between yolk sac cholesterol and IYS-administrated carvacrol in newly hatched chicks.

The increased liver weight observed in the CARV-treated chicks $24 \mathrm{~h}$ post-hatch may be considered as a sharp exposure of the liver to high concentrations of carvacrol and the metabolic responses of liver to detoxify carvacrol. Carvacrol has a small molecule which rapidly dissolves in lipids (Lide, 1998; De Vincenzi et al., 2004). The injected carvacrol may 
have been promptly absorbed into the circulation through the yolk sac membrane with no interaction or binding affinity with yolk components.

\section{Conclusions}

In conclusion, the results of the current study revealed that IYS administration of carvacrol had no effect on rate of cholesterol absorption from yolk sac residuals. This finding suggests that the hypocholesterolemic activity of carvacrol might be exerted through other mechanisms rather than reduced cholesterol absorption and deserves further investigation.

\section{Edited by: M. Mielenz}

Reviewed by: two anonymous referees

\section{References}

Abdollahi, M., Salenia, A., Mortazavi, S. H., Ebrahimi, M., Shafiee, A., and Fuladian, F.: Antioxidant, antidiabetic, antihyperlipidemic, reproduction stimulatory properties and safety of essential oil of Satureja khuzestanica in rat in vivo: A oxicopharmacological study, Med. Sci. Monit., 9, 331-335, 2003.

Connor, W. E., Johnston, R. D., and Lin, D. S.: Metabolism of cholesterol in the tissues and blood of the chick embryo, J. Lipid. Res., 10, 388-394, 1969.

Crowell, P. L.: Prevention and therapy of cancer by dietary monoterpenes, J. Nutr., 129, 775S-778S, 1999.

De Vincenzi, D., Stammati, M. A., De Vincenzi, A. D. E., and Silano, M.: Constituents of aromatic plants: carvacrol, Fitoterapia, 75, 801-804, 2004.

Elliott, R. J.: Ektachem DT-60 Analyzer, The Physician's Leading Comput. J. 2, 6, 1984

Mikec, M., Bidin, Z., Valentic, A., Savic, V., Zelenika, T. A., RaguzDuric, R., Novak, I. L., and Balenovic, M.: Influence of environmental and nutritional stressors on yolk sac utilization, development of chicken gastrointestinal system and its immune status, World Poult. Sci. J., 62, 31-40, 2006.

El-Rokhel, S. M., Yassin, N. A., El-Shenawy, S. M., and Ibrahim, B. M.: Antihypercholesterolaemic effect of ginger rhizome (Zingiber officinale) in rats, Inflammopharmacology, 18, 309-315, 2010.

Elson, C. E. and Qureshi, A. A.: Coupling the cholesterol- and tumor-suppressive actions of palm oil to the impact of its minor constituents on 3-hydroxy-3-methylglutaryl coenzyme A reductase activity, Essential Fatty Acids, 52, 205-208, 1995.

Garcia, M. M.: Hypolipidemic potential of plants used in Cuba, Pharmacology, 1, 73-80, 2014.

Gonzales, E., Konodo, N., Saldanha, É. S. P. B., Loddy, M. M., Careghi, C., and Decuypere, E.: Performance and physiological parameters of broiler chickens subjected to fasting on the neonatal period, Poultry Sci., 82, 1250-1256, 2003.

Hadian, J., Mirjalili, M. H., Kanani, M. R., Salehnia, A., and Ganjipour, P.: Phytochemical and morphological characterization of Satureja khuzistanica Jamzad populations from Iran, Chem. Biodiver., 8, 902-915, 2011.
Jamroz, D. L., Wertelecki, T., Wiliczkiewicz, A., Orda, J., and Skorupinska, J.: Dynamics of yolk sac resorption and post-hatching development of the gastrointestinal tract in chickens, ducks and geese, J. Anim. Physiol. Anim. Nutr., 88, 239-250, 2004.

Jiang, F. and Dusting, G. J.: Natural phenolic compounds as cardiovascular therapeutics: Potential role of their antiinflammatory effects, Curr. Vasc. Pharmacol., 1, 135-156, 2003.

Kaimal, S., Sujatha, K. S., and George, S.: Hypolipidaemic and antioxidant effects of fruits of Musa AAA (Chenkadali) in alloxan induced diabetic rats, Indian J. Exp. Biol., 48, 165-173, 2010.

Khosravinia, H.: Effects of Satureja khuzistanica essential oils in drinking water on mortality, production performance, water intake and organ weights in broiler chickens reared under heat stress condition, Int. J. Biomethrol., 59, 1711-1719, 2015a.

Khosravinia, H.: Hypolipidemic effects of Satureja Khuzistanica essential oil in broiler chicken are realized through alteration in steroid hormones, Kafkas. Univ. Vet. Fak. Derg., 21, 203-209, $2015 b$.

Khosravinia, H.: Physiological responses of newly hatched broiler chicks to increasing journey distance during road transportation, Ital. J. Anim. Sci., 14, 519-523, 2015c.

Lide, D. R.: Handbook of Chemistry and Physics, 87 Edn., CRC Press Boca Raton, FL, 3-346, 1998.

Ostlund, R. E., Racette, S. B., and Stenson, W. F.: Inhibition of cholesterol absorption by phytosterol-replete wheat germ compared with phytosterol-depleted wheat germ, Am. J. Clin. Nutr., 77, 1385-1589, 2003.

Puvadolpirod, S. and Thaxton, J. P.: Model of physiological stress in chickens: 1. Response parameters, Poult. Sci., 79, 363-369, 2000a.

Puvadolpirod, S. and Thaxton, J. P.: Model of physiological stress in chickens: 3. Temporal patterns of response, Poult. Sci., 79, 377-382, 2000b.

Puvadolpirod, S. and Thaxton, J. P.: Model of physiological stress in chickens: 4. Digestion and metabolism, Poult. Sci., 79, 383-390, 2000c.

Qureshi, A. A., Din, Z. Z., Abuirmeileh, N., Burger, W. C., Ahmed, Y., and Elson, C. E.: Suppression of avian hepatic lipid metabolism by solvent extracts of garlic: impact on serum lipids, J. Nutr., 113, 1746-1755, 1983.

Saravanan, M. and Ignacimuthu, S.: Hypocholesterolemic Effect of Indian Medicinal Plants - A Review, Med. Chem., 5, 40-49, 2015.

SAS Institute: SAS User's Guide, Version 9.2 Review Edition, SAS Institute Inc, Cary, NC, 2002.

Steel, R. G. D. and Torrie J. H.: Principles and procedures of statistics: A biometrical approach, 2nd edition, McGraw Hill Book Co., Inc., New York, USA, 1980.

Tankson, J. D., Vizzer-Thaxton Y., Thaxton J. P., May J. D., and Cameron J. A.: Stress and nutritional quality of broilers, Poult. Sci., 80, 1384-1389, 2001.

Teekell, R. A., Breidenstein, C., and Watts, A. B.: Cholesterol metabolism in the chicken, Poult. Sci., 54, 1036-1042, 1975.

Thaxton, J. P. and Puvadolpirod, S.: Model of physiological stress in chickens: 5. Quantitative evaluation, Poult. Sci., 79, 391-395, 2000.

Vijayaraj, P. S., Muthukumar, K., Sabarirajan, J., and Nachiappan, V.: Evaluation of antihyperlipidemic activity of ethanolic extract 
of Cassia auriculata flowers, Indian J. Biochem. Biophys., 48, 54-58, 2011

William, E. C., Johnston, R., and Lin, D. S.: Metabolism of cholesterol in the tissues and blood of the chick embryo, J. Lipid. Res., 10, 388-394, 1969. 